\title{
Paying More Taxes and Affording It Less
}

\author{
NANCY JIANAKOPLOS
}

NE of the many side effects of inflation is that it results in a transfer of resource command from the private sector to the public sector of the economy, The Government's status as a net monetary debtor and the progressive income tax structure are the vehicles by which this resource transfer occurs. This article discusses how inflation and the progressive tax structure interact to generate Government revenue and reduce the take-home pay of taxpayers. ${ }^{1}$

Figures from the Bureau of Labor Statistics show that from the fall of 1973 to the fall of 1974 , personal income taxes for a family of intermediate income rose by 25.1 percent, while the budget necessary to maintain their standard of living rose by 13.5 percent. $^{2}$ Thus, even if a family's income before taxes kept pace with inflation, their disposable income (total income less taxes) decreased as taxes took up an increasing proportion of their budget.

How and why did taxes increase faster than income? What are the economic consequences of this resource transfer and are there possible remedies? In order to answer these questions, the tax liabilities of an individual family over a number of years are examined. Next, the aggregate effects of increased taxation are discussed. Finally, possible remedies for these tax increases are presented.

\section{One raming Exprience}

In 1967 the Bureau of Labor Statistics calculated that an income of $\$ 9,076$ would be required to maintain a family of four at an intermediate standard of living. From this budget $\$ 1,365$, or 15 percent, would be paid as personal taxes (social insurance contributions and personal income taxes). In 1974 the same family would require a budget of $\$ 14,333$ to maintain an intermediate standard of living. Of this amount $\$ 2,790$, or 19.5 percent, would be paid as personal taxes.

\footnotetext{
1For another aspect of inflation serving to finance the government, see Charlotte E. Ruebling, "Financing Government Through Monetary Expansion and Inflation," this Reviet (February 1975), pp. 15-23.

¿A family budget for an intermediate income level totaled $\$ 14,333$ in auturnn 1974 , according to BLS figures. See U.S. Department of Labor, Bureau of Labor Statistics, Auttumn

1974 Urban Family Budgets and Comparative Indexes for Selected Urban Areas, No. 75-190 (April 9, 1975).
}

In order to understand why taxes have taken up an increasing proportion of the family budget, the income and tax liabilities of a typical family are examined over a number of years. The examination consists of comparing the rise in actual tax liabilities with the rise in income, assuming income increases equal the rate of inflation. The Bureau of Labor Statistics (BLS) provides budget information for a hypothetical family of four which consists of a husband, employed full-time; a wife, not employed outside the home; a boy, 13; and a girl, 8 . The BLS constructs budgets for this family at three standards of living - low, intermediate, and high. This study considers the intermediate level family budget. In the spring of 1967 , which is regarded as the base year, this budget equalled $\$ 9,076$. $^{3}$

For illustrative purposes, this base period budget is increased each year at the same rate as the consumer price index (CPI). This increase would allow pre-tax income to keep pace in some measure with the rate of inflation. The CPI is not a complete measure of increases in the cost of living, but it has several attributes which make it suitable for the purposes of this analysis. The CPI is frequently used in union contracts as the measure of changes in the cost of living, activating wage increases for workers covered by the contract. The effects of increases in income and social security taxes are not included in the CPI, but increases in excise, sales, and real estate taxes are included. For this reason only the effects of Federal and state income taxes and social security contributions are considered here.

It is assumed that by increasing the family income each year at the same rate as the increase in the CPI, the pre-tax real income of the family remains constant in terms of 1967 purchasing power. On this basis the family's money income before taxes rose from $\$ 9,076$ in 1967 to $\$ 13,407$ in $1974 .^{5}$

\footnotetext{
Jean C. Brackett, "New BLS Budgets," Monthly Labor Review (April 1969), pp. 3-16.

4 For a review of the adequacies and shortcomings of the CPI, see Denis S. Kamosky, "A Primer on the Consumer Price Index," this Review (July 1974), pp. 2-7.

־This fgure differs from the 1974 BLS budget of $\$ 14,333$ because the BLS budget includes not only those cost-ofliving increases included in the CPI, but also allowances for moreased personal income and social security taxes.
} 


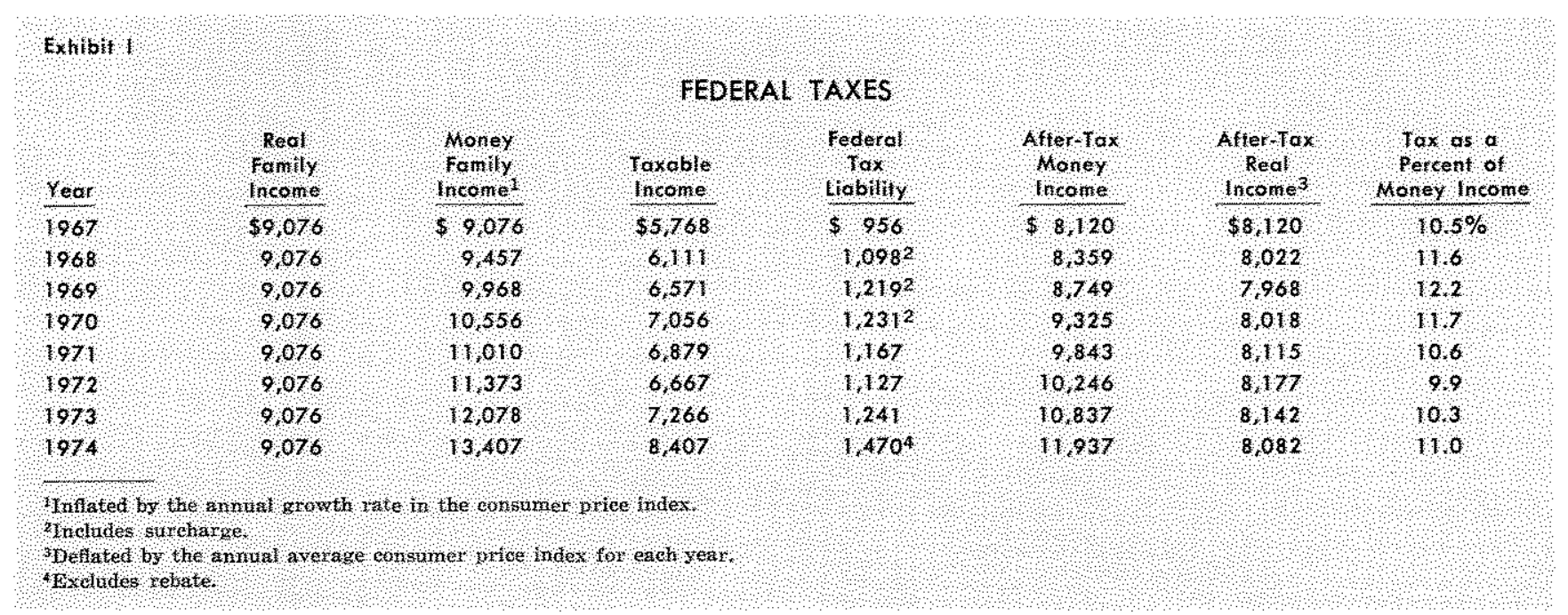

\section{Folenal Tnoome Tax}

The family's Federal income tax liability is calculated using the status of "married filing jointly," claiming four exemptions and using the standard deduction, actual tax rates, exemptions, and deductions applicable from 1967 through $1974 .{ }^{6}$ During this period there were several changes in the Federal income tax structure: income tax surcharges were implemented during 1968, 1969, and 1970, and there were changes in the value of allowable exemptions and the standard deduction in 1970, 1971, and 1972. Tax rates and tax brackets, however, did not change during this period. The 1974 tax rebate is excluded from consideration in this article since it was not paid until 1975

The family's Federal income tax liability increased every year except for 1971 and 1972 (see Exhibit I). In 1974, for example, the family paid $\$ 229$ more in Federal income taxes than in 1973, even though the family's real income before taxes was held constant. Their real income after Federal income taxes actually decreased from $\$ 8,120$ in 1967 to $\$ 8,082$ in 1974 .

Despite tax cuts in 1970 through 1972, the portion of family income paid in Federal income taxes increased from 10.5 percent in 1967 to 11 percent in 1974. The increases were much sharper in the periods when tax laws remained the same. For example, from 1967 to 1969 , Federal income taxes as a percent of the family income increased from 10.5 to 12.2 .

The progressive tax structure in combination with inflation was a major cause of taxes accounting for

GIf applicable exemptions and deductions in either 1967 or 1974 had been used for all years, the conclusions reached would have been the same, but the real income lost through the combination of inflation and taxes would have been greater. an increasing share of the family budget. Taxes are paid on money income, and as money income in. creases, the taxpayer can be pushed into a higher tax bracket. The hypothetical family was pushed into a higher bracket in 1974 when its taxable income rose above $\$ 8,000$. Prior to this, 19 cents of the marginal dollar of taxable income was collected as tax, whereas in 1974, 22 cents of the marginal dollar was paid in taxes. Therefore, the effect of the progressive tax structure is to tax more than a proportional share of income increases, even if these increases do not result in increased purchasing power.

\section{Socul Secutity Thers}

The family's social security tax liability is calculated by applying the rates in effect from 1967 to 1974 to the family's money income (see Exhibit II). This family's income is above the taxable ceiling in every year and, therefore, the maximum contribution is paid each year.

In every year from 1967 through 1974 , except 1970 , the family's social security tax liability increased. This is because in every year, except 1970, the taxable income ceiling and/or the rate of employee contribution was raised. The family's social security liability increased from $\$ 290$ in 1967 to $\$ 772$ in 1974. Social security taxes as a percent of the hypothetical family's money income rose from 3.2 percent in 1967 to 5.8 percent in 1974. Increases in social security taxes were much greater than increases in family income. The family's money income rose by 48 percent in the period from 1967 to 1974 while social security contributions increased by 166 percent. Real income, after social security contributions were deducted, fell from $\$ 8,786$ to $\$ 8,555$. This was a loss of $\$ 231$ of 1967 purchasing power due to this tax alone. 


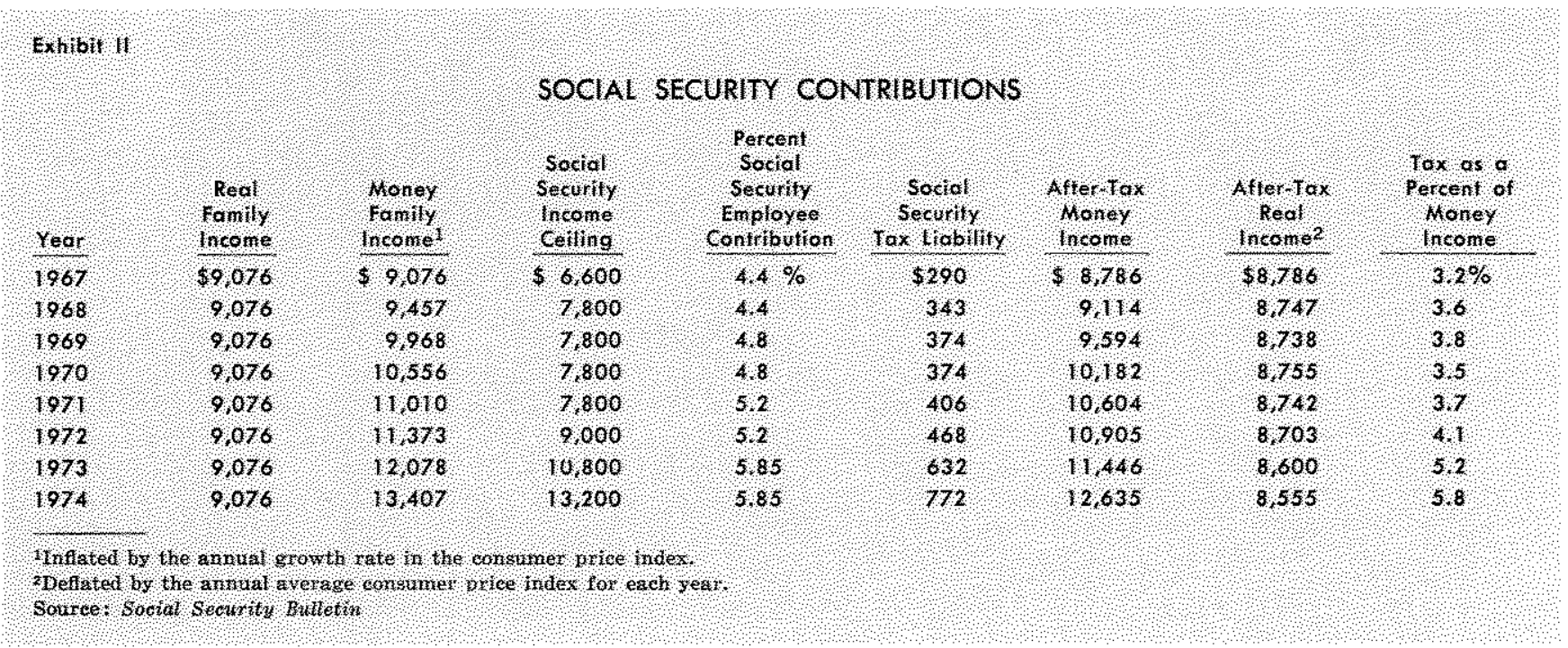

The social security tax changes were implemented in order to finance increased benefits which were legislated in an attempt to help recipients keep pace with the rising cost of living. Therefore, inflation was a major factor necessitating increased social security taxes. ${ }^{7}$ Beginning in January 1975, increases in social security benefits are linked directly to changes in the consumer price index, making the inflation-social security tax relationship more direct.

\section{Shate Income Tares}

The family's state personal income tax liability is calculated by assuming that they lived in Missouri, filed a "joint-married" return, claimed four exemptions and used the standard deduction. The Federal income tax calculated in Exhibit $I$, as well as the standard deduction and personal exemptions applicable, were deducted from income in order to obtain a figure for income taxable by the state. Missouri tax rates were increased in 1971. The structure of the Missouri personal income tax was changed in 1973 to conform with the Federal income tax structure.

State personal income taxes affected the family's budget in a manner very similar to Federal personal income taxes (see Exhibit III): the state tax liability increased from $\$ 82$ in 1967 to $\$ 198$ in 1974 ; the percentage of the family's money income paid in the form of state income taxes increased from 0.9 percent in 1967 to 1.5 percent in 1974; and after-tax real income

The changing age distribution of the population and expanded programs were also contributory factors. For a further discussion of the social security system, see Richard $A$. Musgrave and Pegry B. Musgrave, Public Finance in Theory and Practice (New York: MoGraw-Hint Book Company, $1973)$, pp. $346-350,390-395,666-676$. fell from $\$ 8,994$ to $\$ 8,943$ over the period. Since Missouri state tax rates are lower than Federal tax rates, the dollar increase in state tax liabilities was not as great as for the Federal tax. ${ }^{8}$ However, Missouri brackets are narrower than Federal brackets so that the family was pushed into higher brackets more frequently.

The family did receive some relief from increased state income taxes as a result of their increased Federal tax liability. Federal income taxes are deductible items in calculating Missouri state income tax, and thus the increasing Federal tax reduced to a certain degree the amount of income taxable by the state. Nevertheless, the family lost purchasing power over the period as a result of increasing state taxes.

\section{Combined Tru Burdent}

A look at the composite effect of Federal and state income taxes and social security contributions shows that in every year taxes increased above the previous year's level (see Exhibit IV). The hypothetical family's combined tax liability increased from $\$ 1,328$ to $\$ 2,440$. In terms of 1967 purchasing power, the family's income remained unchanged at $\$ 9,076$, while their tax liability, also in terms of 1967 purchasing power, increased by $\$ 324$. In 1967, taxes took 14.6 percent of the family budget. By 1974 the figure had climbed to 18.2 percent. Inflation and taxes had conbined to erode their income despite the fact that they received annual cost-of-living increases.

\footnotetext{
sThe family's income was in the 4.5 percent bracket for 1974 Missouri stafe income taxes, compared to the 22 percent bracket for Federal income taxes.
} 


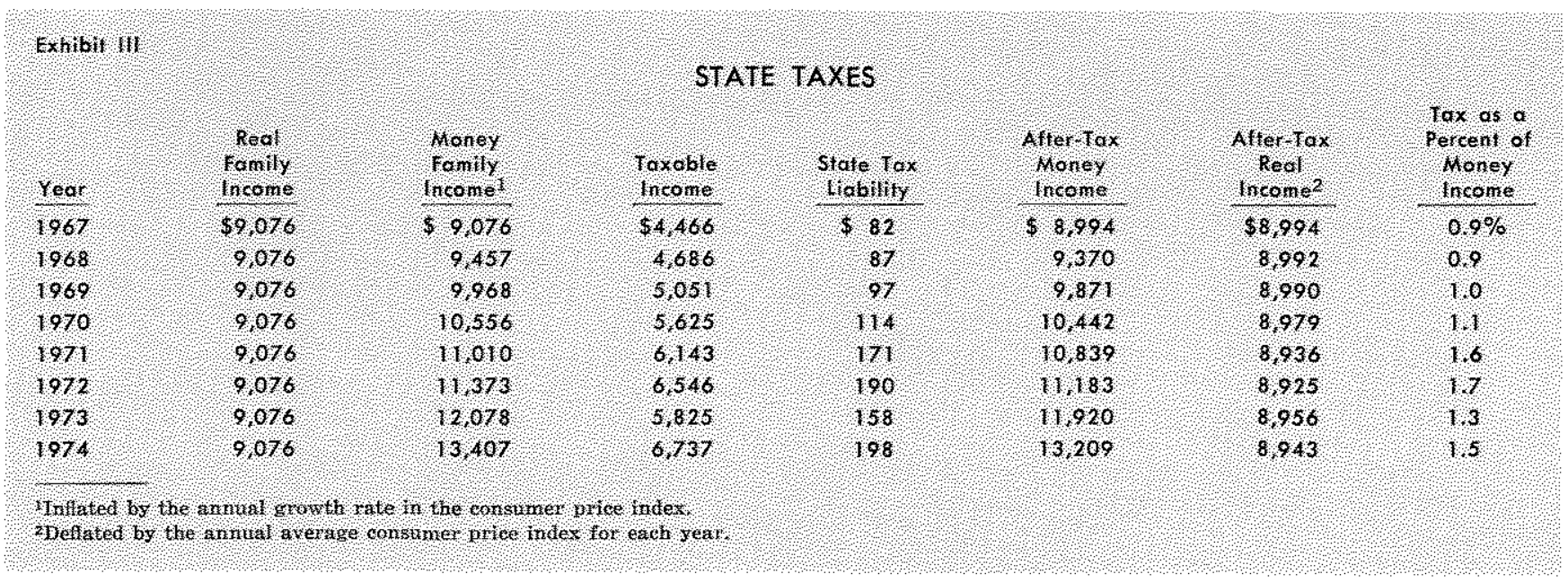

\section{The Aggregate Experience}

Inflation in combination with the progressive tax structure serves to increase the government's share of
In times of inflation, the tax system generates an automatic restraint on private spending by increasing the government's proportion of private income. Like-

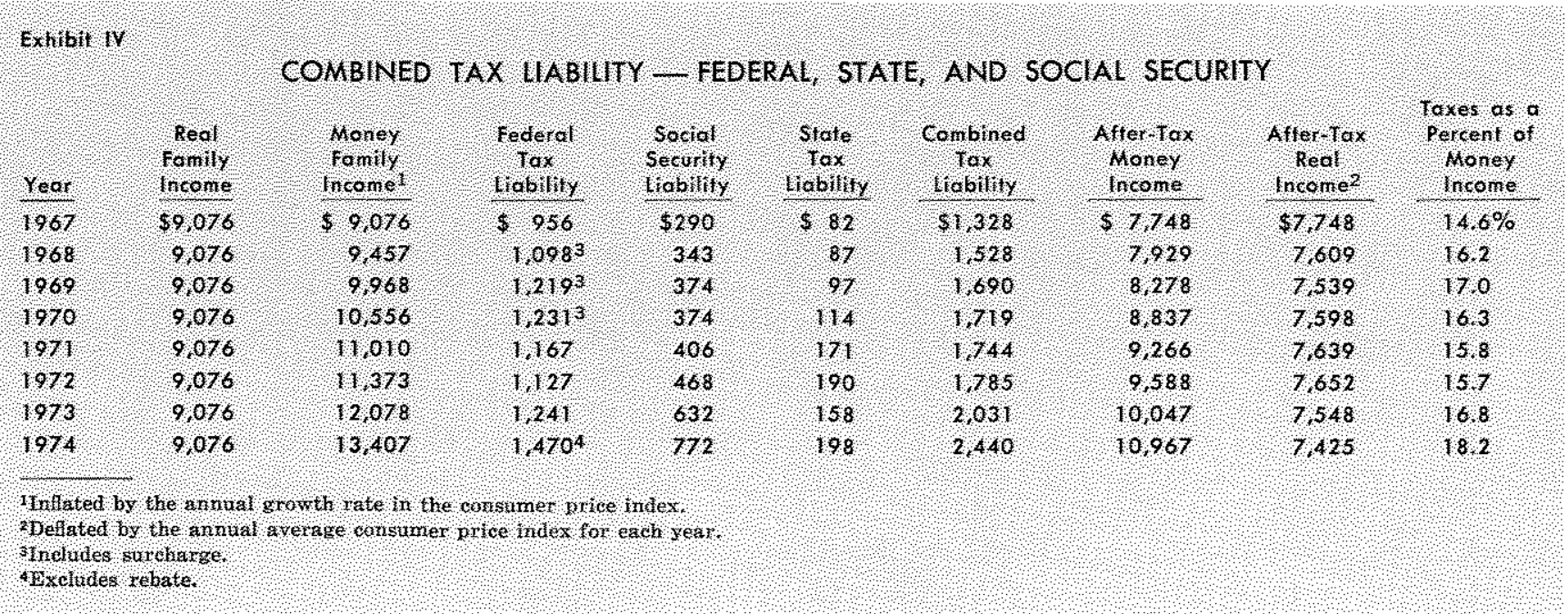

national income. The increase is more than proportional to the increase in household incomes because as incomes rise, some people whose incomes were too low to be taxed are now taxed, and others, as in the previous example, are pushed into higher marginal tax brackets. Inflation has the effect of an "unauthorized" (in contrast to a legislated change in the tax structure) tax rate increase. This increase in taxes shifts com. mand over resources from the private sector to the government sector, and thus dampens private demand.

The tax system, as currently formulated, has what is often referred to as a "built-in stabilizing" feature."

\footnotetext{
${ }^{9}$ For a theoretical discussion of built-in stabilizers, see Armen A. Alchian and Wiliam R. Allen, University Economics: Elements of Inquiry, 3rd ed. (Belmont, California: Wadsworth Publishing Company, Ine., 1972), pp. 716-718.
}

wise, in times of demand-induced recessions, the tax structure is intended to exhibit a stabilizing influence on private incomes by reducing the proportion of income which is transferred from the private sector to the public sector by taxes. In all previous postwar recessions, personal taxes as a percent of personal income declined or remained constant (see accompany ing chart). However, the recent recession, which in its early stages was supply-induced rather than demand-induced, was accompanied by severe inflation. ${ }^{10}$ Taxes as a percent of personal income increased from 14.3 percent in 1973 to 14.8 percent in 1974. Rather than cushioning the recessionary tendencies, the "built-in stabilizers" associated with taxes

loSee Norman N. Bowsher, "Two Stages to the Current Recession," this Review (June 1975), pp. $2-8$. 


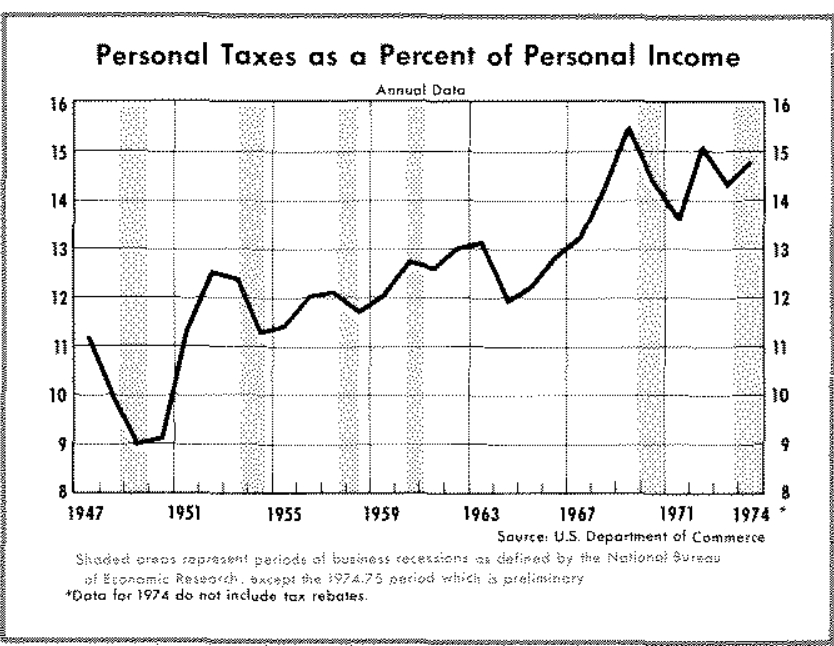

served to amplify this cyclical downswing in private spending.

\section{Some Posible Remeries}

There are several ways that "unauthorized" tax increases resulting from inflation could be controlled. A tax rebate system could return to the taxpayer precisely the amount of inflation-induced tax collections. The Committee on Internal Revenue Taxation has estimated that $\$ 7$ billion of the $\$ 15$ billion increase in 1974 Federal income taxes resulted from the interaction of inflation and the tax structure. It also estimated the average inflation-induced tax per return by income brackets (see Table I). Using these estimates of the impact of inflation on Federal income taxes, the hypothetical family would have received a $\$ 75$ rebate. ${ }^{11}$ Rebates would be higher for higher income families, but a greater percentage of the taxes paid by lower income families would be returned.

As the examples of the hypothetical family's tax liabilities indicated, increased deductions and exemptions gave the family some short-term relief from inflationary tax increases. An annual increase in the size of the standard deduction, exemptions, and tax bracket ceilings could offer a long-term solntion. The increases could be based on the increase of a particular price index in a manner similar to the treatment of family income in Exhibits I-IV. This indexation would help to eliminate "unlegislated" tax increases. ${ }^{12}$

11. It should be noted that the rebate system described in this case would be used only to return inflation-induced taxes, not to stimulate economic activity.

12For a more complete discussion of indexation, see Iai-Hoon Yang, "The Case For and Against Indexation; An Attempt at Perspective," this Review (October 1974), pp. 2-11.

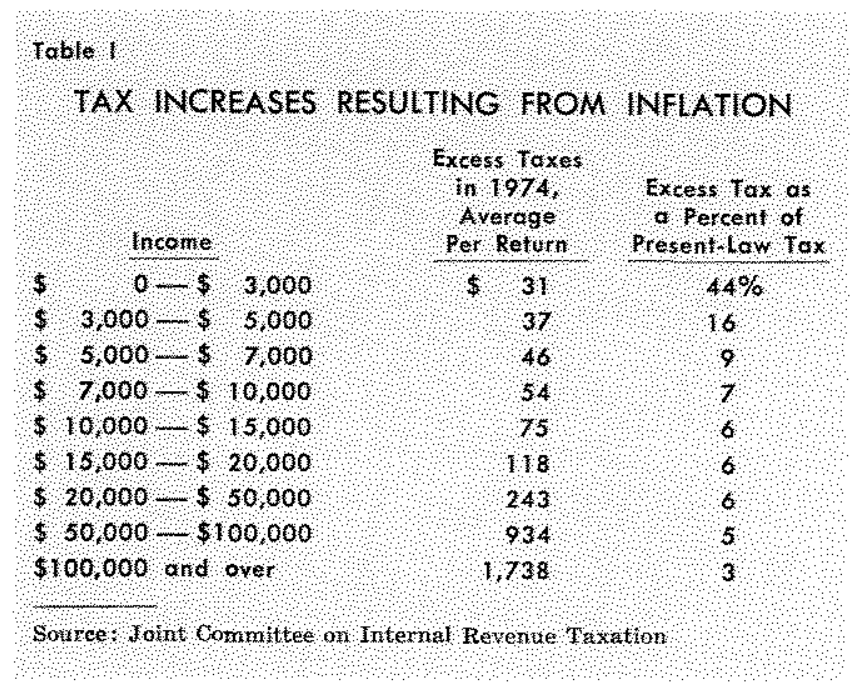

An alternative method of indexation would be to deflate family income and itemized deductions by the price index rather than inflate the exemptions and the standard deductions. The tax calculated in this manner would then have to be reinflated so that payments would be in current dollars. The tax system would then approach a system of taxing real income rather than money income.

\section{Conchaton}

The most effective method to avoid inflationinduced increases in tax payments is to attack the problem at the core. It is the interaction of inflation and the tax structure which results in the more than proportional increase in taxes. Either stabilizing the price level or changing the progressive structure of the tax rates conld relieve the taxpayer of the burden of infation-induced tax increases.

By using tax rebates, indexing the tax strueture, or stabilizing prices, inflation-induced tax increases could be avoided, but such schemes deal with symptoms, not the disease of inflation itself. Since 1967, a taxpayer whose income kept pace with inflation actually lost purchasing power, and inflation in combination with the progressive tax structure served as a vehicle to transfer resources from the private sector to the public sector. Stabilization policy takes on even greater importance when not only the obvious consequences of a changing price level are noted, but also when the less apparent consequences, such as the "unauthorized" tax increases resulting from inflation, are recognized. 